УДК: 543.4:535.6

A. N. Chebotaryov, D. V. Snigur, K. V. Bevziuk, I. S. Efimova

Department of Analytical Chemistry, Odessa I. I. Mechnikov National University, 65082,

Odessa, Ukraine, alexch@ukr.net

\title{
THE YELLOWNESS INDEX USE FOR THE ACID-BASE EQUILIBRIUM STUDY IN XYLENOL ORANGE AQUEOUS SOLUTIONS
}

\begin{abstract}
The possibility of the yellowness index use for the acid-base equilibrium study and ionization constants determination in dyes solutions is studied. It is shown that the yellowness index is suitable for the set task. Its use enables a more reasonable mathematical apparatus algorithmization, automation, simplification and in comparison with the existing approaches of the chemical chromaticity method and classical physico-chemical methods. Key words: yellowness index, acid-base equilibrium, ionization constants, coordinates of color, xylenol orange.
\end{abstract}

\section{Introduction}

The aim of study is to establish the dyes physicochemical and acid-base characteristics of the reagents that are realized in the solutions with a broad values change of acidity or solvents. Also there is the determination of ionization constants (pK) and the spectral characteristics of individual reagents states or forms. The knowledge of $\mathrm{pK}$ values provides a basis for understanding of the chemical reactions between the compound of interest. Additionally, they play a major role in acid-base titrations, complex formation and various analytical procedures. Also, the $\mathrm{pK}$ values of a compound influence many characteristics such as its reactivity, spectral properties (color). Consequently, several publications were devoted to the determination of $\mathrm{pK}$ experimentally and theoretically $[1,2]$.

Nowadays interest in the chemical chromaticity (CC) method (tristimulus colorimetry method) has grown very much. The CC method approaches have been applied to create test methods [3], to assess the food quality [3, 4], as well as to study acid-base equilibrium in organic dyes solutions and analytical reagents $[3,5]$. It is recommended to use a saturation (S) function and its derivative - the specific color discrimination for ionization constants determination in the dyes solutions $[3,6]$. Yellowness Index is the indicator that describes the color change of the sample from white to yellow, and is calculated from the array of spectrophotometric data. Its calculation is methodologically simpler and easy to automatize. The yellowness index is used to assess the textile and food industries quality [5-8]. In this study we investigated the possibility of a more informative yellowness index $\left(\mathbf{Y}_{\mathbf{I}}\right)$ use for acid-base equilibrium study and ionization constants determination.

\section{Material and methods}

\subsection{Apparatus}

Acid-base equilibrium in dyes solutions was studied by the UV/VIS-spectroscopy and chemical chromaticity methods using a spectrophotometer SF-56 (OKB 
«LOMO-Spektor», St.-Petersburg, Russia) in the wavelength range $380-780 \mathrm{~nm}$ in quartz cuvettes with the thickness of the absorbing layer $1 \mathrm{~cm}$. The medium's acidity was controlled by pH meter I-130 («ZIP», Gomel, Belarus).

\subsection{Reagents}

Xylenol orange (Merck) (XO) was chosen as a dye, whose functional - analytical groups are characterized by the reliably determined $\mathrm{pK}$ (table 1 ). The initial XO solution with $10^{-3} \mathrm{M}$ concentration was made by sample dissolution $(\mathrm{m}=0,1682 \mathrm{~g})$ in $250 \mathrm{ml}$ of distilled water. Solutions with lower concentrations were prepared by dilution of initial solution. The medium acidity was created by sulfuric acid and sodium hydroxide.

Table 1

Xylenol orange ionization constants

\begin{tabular}{|c|c|c|c|c|c|c|}
\hline \multirow{2}{*}{ № } & \multirow{2}{*}{ Group } & \multicolumn{5}{|c|}{ Method } \\
\cline { 3 - 7 } & & \multicolumn{2}{|c|}{ Potentiometry [9, 10] } & \multicolumn{2}{|c|}{ Spectrophotometry [9] } & CC [11] \\
\hline 1 & $-\mathrm{SO}_{3} \mathrm{H}$ & - & - & $-1,74$ & - & $-1,73$ \\
\hline 2 & $=\mathrm{OH}^{+}$ & - & - & $-1,09$ & - & $-1,10$ \\
\hline 3 & $-\mathrm{COOH}$ & - & - & 0,76 & - & 0,70 \\
\hline 4 & $-\mathrm{COOH}$ & 2,06 & 2,00 & - & - & 1,12 \\
\hline 5 & $-\mathrm{COOH}$ & 2,16 & 2,74 & - & 2,60 & 2,53 \\
\hline 6 & $-\mathrm{COOH}$ & 3,56 & 4,49 & - & 3,70 & 3,05 \\
\hline 7 & $-\mathrm{OH}$ & 7,34 & 7,50 & 6,46 & 6,40 & 6,31 \\
\hline 8 & $\equiv \mathrm{NH}^{+}$ & 9,68 & 10,30 & 10,46 & 8,40 & 10,45 \\
\hline 9 & $\equiv \mathrm{NH}^{+}$ & 12,61 & 12,00 & 12,28 & 12,20 & 12,38 \\
\hline
\end{tabular}

\subsection{Procedures}

The necessary medium acidity was created for $\mathrm{pK}$ determination. It was provided by putting the dye's aliquot of solution into the $50 \mathrm{ml}$ flask. The obtained solutions absorption spectrum were registered and coordinates of color XYZ were calculated from the array of spectrophotometry data. Parameter $\mathrm{Y}_{\mathrm{I}}$ was calculated by formulae:

$$
Y_{I}=\frac{100(1,28 X-1,06 Z)}{Y}
$$

where $\mathrm{Y}_{\mathrm{I}}$ - yellowness index; $\mathrm{X}, \mathrm{Y}, \mathrm{Z}$ - coordinates of color in the CIEXYZ color space.

\section{Results and discussion}

\subsection{Effect of the medium acidity}

The absorption spectra of $\mathrm{XO}$ in aqueous solution were studied by various the medium's acidity. Figure 1 (parts $\mathbf{a}$ and $\mathbf{b}$ ) shows the changes in the absorption spectra of XO.

Figure 1 shows the changes in the absorption spectra of XO. As can be seen from fig. 1 (a) in the acidic medium XO has absorption bands at $430-460 \mathrm{~nm}$ (curves 2, 3), 
505-515 nm (curve 1) and absorption band with maximum at 670 $\pm 10 \mathrm{~nm}$ (curve 4). Increasing the concentration of $\mathrm{OH}$-groups in the solution contributes to formation of new acid-base forms of XO.

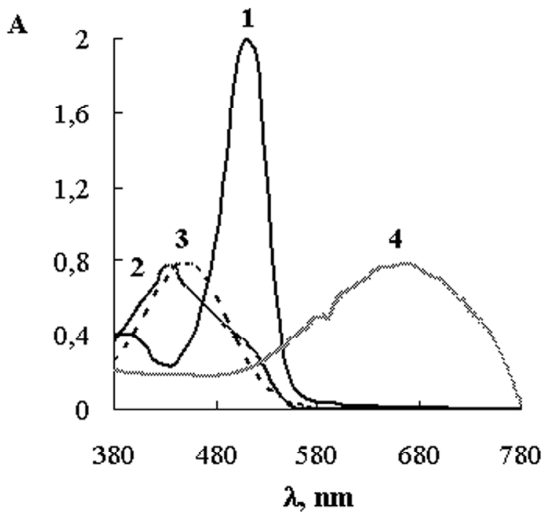

a

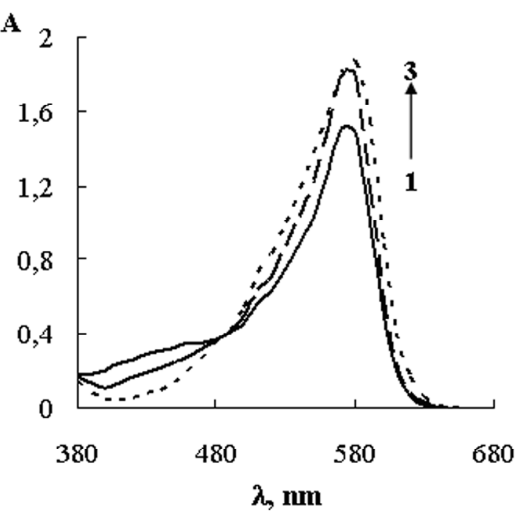

b

Fig. 1. The electronic absorption spectra of the xylenol orange solution in acidic (part a: $1-18 \mathrm{M} \mathrm{H}_{2} \mathrm{SO}_{4}$ medium, $2-\mathrm{pH} \mathrm{1,3-pH} \mathrm{3,4-pH} \mathrm{5)} \mathrm{and} \mathrm{alkaline}$ (part b: $1-\mathrm{pH} \mathrm{8,2-pH} \mathrm{10,3-pH} \mathrm{13)} \mathrm{media.}$

They are characterized by isosbestic point at $490 \mathrm{~nm}$ and absorption maxima at 575 nm (fig. 1 b, curves 1-3). The observed changes in the absorption spectra are explained the acid-base equilibria in XO solution. Each balance describes appropriate $\mathrm{pK}$ values.

\subsection{Determination of $\mathrm{pK}$ values}

We studied the possibility of the yellowness index use for determining the dye $\mathrm{pK}$ values. Figure 2 shows the $\mathrm{Y}_{\mathrm{I}}$ dependence of the medium acidity.

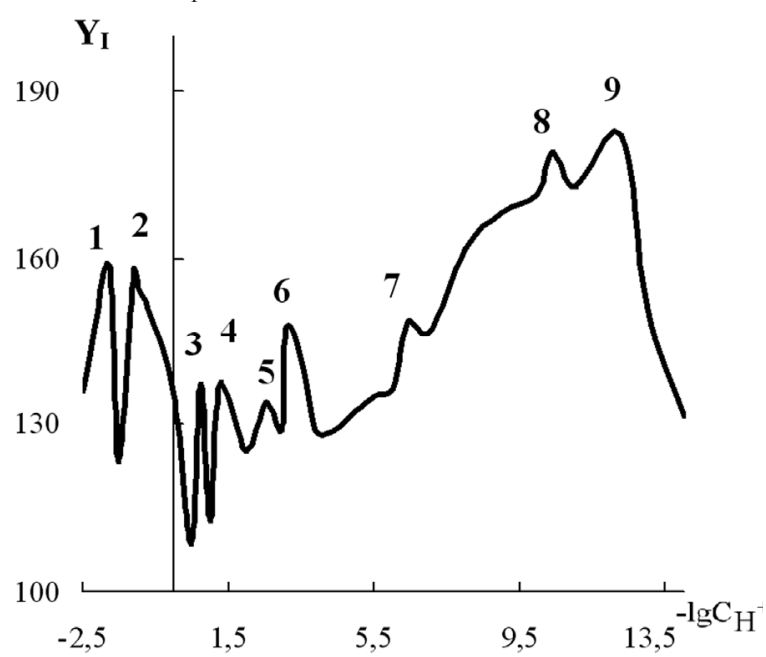

Fig. 2. The $Y_{I}$ dependence of the xylenol orange solution on the medium's acidity 
It is known that for an absolutely white body $-Y_{I}=0$, for yellow and red ones $-Y_{1}>0$; for blue and green ones $-Y_{I}<0$. The fracture's points on the curve of $Y_{I}$ values dependence from $\mathrm{pH}$ corresponds to the areas of transition from one form to another. The corresponding values $-\operatorname{lgCH}^{+}$are received by finding the coordinates of each peak, which are numerically equal to the values of the $\mathrm{XO} \mathrm{pK}$ in solution. The formation of 9 peaks confirms the presence of 9 values of $\mathrm{pK}$ (table 1) for different molecule forms of the $\mathrm{XO}$ in the solution, each of which is characterized by specific $Y_{I}$ values, whose sign indicates the solution reagent color in a wide range of medium's acidity. The graphic dependence analysis (fig. 2) points to the existence of ten differently charged forms of XO in solution, which depend on the medium acidity and are in dynamic equilibrium; each of which is characterized by $\mathrm{pK}$ value (table 2).

Table 2

Xylenol orange ionization constants installed by using the yellowness index $(n=3 ; P=0,95)$

\begin{tabular}{|c|c|c|}
\hline № & Group & $\mathrm{pK}$ \\
\hline 1 & $-\mathrm{SO}_{3} \mathrm{H}$ & $-1,75 \pm 0,03$ \\
\hline 2 & $=\mathrm{OH}^{+}$ & $-1,10 \pm 0,03$ \\
\hline 3 & $-\mathrm{COOH}$ & $0,75 \pm 0,03$ \\
\hline 4 & $-\mathrm{COOH}$ & $1,25 \pm 0,03$ \\
\hline 5 & $-\mathrm{COOH}$ & $2,50 \pm 0,03$ \\
\hline 6 & $-\mathrm{COOH}$ & $3,10 \pm 0,03$ \\
\hline 7 & $-\mathrm{OH}$ & $6,41 \pm 0,03$ \\
\hline 8 & $\equiv \mathrm{NH}^{+}$ & $10,42 \pm 0,03$ \\
\hline 9 & $\equiv \mathrm{NH}^{+}$ & $12,35 \pm 0,03$ \\
\hline
\end{tabular}

The results (Table 2) correlate with those presented in Table 1 literature data, which indicates that the results are reliable and the yellowness index use for the acid-base properties study and the establishment of the corresponding values of the dyes' molecules and organic analytical reagents $\mathrm{pK}$ are suitable.

The yellowness index use allows to simplify the calculations in comparation with the specific color differences parameter. The algorithm of $\mathrm{pK}$ definition with the specific color discrimination has the following form:

absorption spectrum - the color coordinates $X Y Z$ - the color coordinates $L A B$ - the color saturation $S$-parameter specific color discrimination - the dependence identification of the $S C D=f\left(-\lg C \mathrm{H}^{+}\right)$- definition of the $\mathrm{pK}$.

The algorithm is simplified by using the yellowness index:

absorption spectrum - the color coordinates $X Y Z$ - the yellowness index $Y_{I}$-the dependence identification of the $Y_{I}=f\left(-\lg \mathrm{CH}^{+}\right)$-definition of the $\mathrm{pK}$. 


\section{Conclusion}

Thus, the use of color characteristics of chemical systems in chemistry of dyes enhances the study of their acid-base equilibria. Also it should be noted that the chemical chromaticity method compared to other physico-chemical methods (spectrophotometry, potentiometry, etc.) provides more complete information about available and appropriate protolytic equilibria constants. As a result of our work we established the principal possibility of the yellowness index use for the acid-base equilibrium study and $\mathrm{pK}$ determination in the dyes solutions. The yelowness index allows to simplify and reduce the mathematical apparatus instead of the existing approaches of chemical chromaticity method and classical physico-chemical methods.

\section{References}

1. Ebead Y.H., Salman H.M.A., Abdellah M.A. Experimental and theoretical investigations of spectral, tautomerism and acidebase properties of Schiff bases derived from some amino acids. Bull. Korean Chem. Soc. 2010; 31: $850-858$

2. Ebead Y.H. The role of the medium on the acid dissociation constants of some azo dyes in view of experimental and theoretical data. J. Mol. Struct. 2010; 982: 100 - 106.

3. Ivanov V.M., Kuznetsova O.V. Chemical chromaticity: potential of the method, application areas and future prospects. Russ. Chem. Rev. 2001; 70: $357-373$.

4. Mateo R., Bosch-Reig F. Classication of Spanish unioral honeys by discriminant analysis of electrical conductivity, color, water content, sugars, and pH. J. Agric. Food Chem. 1998; 46: 393 - 400.

5. Prasad K., Raheem S., Vijayaleksmi P., Sastri C. Basic aspects and applications of tristimulus colourimetry. Talanta. 1996; 43: 1187 - 1206.

6. Somkiat P., Saijai S., Supranee S., Thitikorn P., Somchart S., Adisak N. Kinetics of colour change during storage of dried garlic slices as affected by relative humidity and temperature. J. Food Eng. 2004; 62: 1 - 7.

7. Jha S.N., Kingsly A.R.P., Chopra S. Non-destructive determination of firmness and yellowness of mango during growth and storage using visual spectroscopy. Biosys. Eng. 2006; 94 : 397 - 402.

8. Corzo O., Bracho N., Marjal J. Color change kinetics of sardine sheets during vacuum pulse osmotic dehydration. J. Food Eng. 75 (2006) 21 - 26.

9. Hulanicki A., Glab S., Ackerman G. Compleximetric indicators: characteristics and applications. Pure \& Appl. Chem. 1983; 55: 1137 - 1230.

10. Ghjlivand M.B., Bamdad F., Chasemi J. A potentiometeric study of protonation and complex formation of xylenol orange with alkaline earth and aluminum ions. Talanta. 1998; 46: 875 - 894 .

11. Chebotaryov A.N., Efimova I.S., Borisyuk N.A., Snigur D.V. Chemical chromaticity method in the study of acid-base properties of phytogenous dyes. Methods and objects of chemical analysis. 2011; 6: $207-213$ (in Ukrainian)

Стаття надійшла до редакції 21.01.13 
О. М. Чеботарьов, Д. В. Снігур, К. В. Бевзюк, І. С. Єфімова

Одеський національний університет імені I. I. Мечникова, кафедра аналітичної хімії, вул. Дворянська, 2, Одеса, 65082,

alexch@ukr.net

\section{ФУНКЦІЯ ПОКАЗНИКА ЖОВТИЗНИ ПРИ ДОСЛІДЖЕННІ КИСЛОТНО-ОСНОВНИХ РІВНОВАГ КСИЛЕНОЛОВОГО ОРАНЖЕВОГО У ВОДНИХ РОЗЧИНАХ}

\section{Резюме}

Вивчено можливість застосування функції показника жовтизни для дослідження кислотно-основних рівноваг і визначення констант іонізації ксіленолового оранжевого у водних розчинах. Показано, що використання даної функції дозволяе спростити математичний апарат, алгоритмізацію та автоматизацію розрахунків, у порівнянні з існуючими підходами методу хімічної кольорометрії та класичними фізико-хімічними методами.

Ключові слова: показник жовтизни, кислотно-основні рівноваги, константи іонізації, координати кольору, ксиленоловий оранжевий.

\section{А. Н. Чеботарёв, Д. В. Снигур, Е. В. Бевзюк, И. С. Ефимова}

Одесский национальный университет имени И. И. Мечникова

65082, Одесса, ул. Дворянская, 2,

alexch@ukr.net

\section{ФУНКЦИЯ ПОКАЗАТЕЛЯ ЖЕЛТИЗНЫ ПРИ ИЗУЧЕНИИ КИСЛОТНО-ОСНОВНЫХ РАВНОВЕСИЙ КСИЛЕНОЛОВОГО ОРАНЖЕВОГО В ВОДНЫХ РАСТВОРАХ}

Изучена возможность применения функции показателя желтизны для исследования кислотно-основных равновесий и определения констант ионизации ксиленолового оранжевого в водных растворах. Показано, что использование данной функции позволяет упростить математический аппарат, алгоритмизацию и автоматизацию расчетов, в сравнении с существующими подходами метода химической цветометрии и классическими физико-химическими методами.

Ключевые слова: показатель желтизны, кислотно-основные равновесия, константы ионизации, координаты цвета, ксиленоловый оранжевый. 